\title{
Dental School
}

National Cancer Institute

\section{Source}

National Cancer Institute. Dental School. NCI Thesaurus. Code C52652.

A professional school offering coursework leading to a degree in the field dentistry. 